\title{
Storage of milk powders under adverse conditions
}

\section{Influence on the content of water-soluble vitamins}

\author{
BY J. E. FORD \\ National Institute for Research in Dairying, Shinfield, Reading RG2 9AT, Berkshire \\ AND R. F. HURRELL AND P. A. FINOT \\ Research Department, Nestlé Products Technical Assistance Co. Ltd, \\ CH-1814 La Tour-de-Peilz, Switzerland
}

(Received 23 August 1982 - Accepted 10 January 1983)

1. Storage of milk powder under unfavourable conditions accelerates the normally slow deterioration in nutritional quality. The effects of such storage on the water-soluble vitamin composition were examined.

2. (a) Spray-dried whole milk containing $25 \mathrm{~g}$ water $/ \mathrm{kg}$ was stored at $60^{\circ}$ and $70^{\circ}$ and sampled weekly to 9 weeks. (b) Spray-dried whole milk and skimmed milk were adjusted to contain 40 and $100 \mathrm{~g}$ water $/ \mathrm{kg}$ and stored at $37^{\circ}$ in nitrogen and in oxygen. Samples were taken for analysis at intervals during storage.

3. The samples were analysed for eight B-complex vitamins and ascorbic acid, and also for total lysine, "reactive lysine' and 'lysine as lactulosyl-lysine'.

4. Storage at $60^{\circ}$ caused rapid destruction of folic acid ( $53 \%$ loss at 4 weeks) and slower loss of thiamin, vitamin $B_{6}$ and pantothenic acid ( $18 \%$ at 8 weeks). There was no change in the content of riboflavin, biotin, nicotinic acid and vitamin $\mathrm{B}_{12}$. At $70^{\circ}$ the rate of destruction of the four labile vitamins was much increased; $18 \%$ or less survived at 4 weeks.

5. At $37^{\circ}$ and $40 \mathrm{~g}$ water $/ \mathrm{kg}$ there was little change in total and 'reactive' lysine during storage for $57 \mathrm{~d}$. Lactulosyl-lysine was demonstrably present but at low concentration. There was considerable loss of folate ( $72 \%)$ and ascorbate $(91 \%)$ during storage for $30 \mathrm{~d}$ in $\mathrm{O}_{2}$, but no significant loss in $\mathrm{N}_{2}$. Thiamin fell by approximately $12 \%$ in $57 \mathrm{~d}$, equally in $\mathrm{O}_{2}$ and $\mathrm{N}_{2}$. The content of the remaining vitamins was unchanged. At $100 \mathrm{~g}$ water $/ \mathrm{kg}$ there were progressive Maillard changes. During $27 \mathrm{~d}$ in $\mathrm{N}_{2}$ the colour changed from cream to pale brown, but in $\mathrm{O}_{2}$ there was no perceptible colour change. Total lysine fell by $20 \%$ in $27 \mathrm{~d}$, and 'reactive lysine' by $30 \%$. Folate was stable during $16 \mathrm{~d}$ in $\mathrm{N}_{2}$, but largely $(94 \%)$ destroyed in $\mathrm{O}_{2}$. Ascorbic acid was also destroyed in $\mathrm{N}_{2}$ as in $\mathrm{O}_{2}$. Thiamin fell by $41 \%$ in $27 \mathrm{~d}$, equally in $\mathrm{O}_{2}$ and $\mathrm{N}_{2}$. Vitamin $\mathrm{B}_{6}$ was more labile, especially in $\mathrm{N}_{2}$, falling by $71 \%$ in $16 \mathrm{~d}$.

6. With skimmed-milk powder containing $100 \mathrm{~g}$ water $/ \mathrm{kg}$, storage at $37^{\circ}$ in $\mathrm{O}_{2}$ and $\mathrm{N}_{2}$ gave much the same results as for the corresponding whole-milk powder. The presence of milk fat had no marked effect on the stability of the water-soluble vitamins.

7. Destruction of vitamins was clearly linked to the progress of Maillard-type reactions and was strongly influenced by time and temperature of storage, moisture content and, in some instances, by the presence of $\mathrm{O}_{2}$.

Prolonged storage of whole-milk powder at temperatures below $38^{\circ}$ causes little or no change in the content of several of the B-complex vitamins. Thus, Mattick et al.(1945) found no loss of riboflavin or thiamin in whole-milk powder packed in air or inert gas, during storage for 12 months at room temperature. Ascorbic acid decreased by $<50 \%$ in air-packed samples but to a lesser extent in samples packed in inert gas. Sharp et al. (1945) extended these findings, reporting that storage of whole-milk powder for 6 months at $37.8^{\circ}$, in air or inert gas, caused no loss of riboflavin, nicotinic acid, pantothenic acid, biotin or vitamin $\mathbf{B}_{6}$. The content of ascorbic acid declined, by approximately $32 \mathrm{mg} / \mathrm{kg}$ with air-packing and $8 \mathrm{mg} / \mathrm{kg}$ with inert gas.

If, however, the conditions of storage are such as to promote Maillard-type reactions, as by an increase in temperature of storage or in moisture content of the milk powder, then considerable damage to the nutritional quality may ensue. The protein nutritional quality is impaired, mainly as a consequence of degradation of the lysine residues, and there are concomitant losses of several vitamins. 
The present paper reports the effects of storage of low-moisture milk powder at high temperatures, as described by Hurrell et al. (1983), on the B-complex vitamins and vitamin $\mathrm{C}$, and presents for comparison values for 'reactive lysine' and 'lysine as lactulosyl-lysine' (Finot et al. 1981). Experiments are also described in which the moisture content of the milk powder was increased to induce Maillard damage. Dried whole milk and dried skimmed milk were adjusted to contain $100 \mathrm{~g}$ water $/ \mathrm{kg}$ and stored at $37^{\circ}$ in $\mathrm{N}_{2}$ and in $\mathrm{O}_{2}$.

\section{EXPERIMENT A L}

\section{Test materials}

Spray-dried whole-milk powder containing $25 \mathrm{~g}$ water $/ \mathrm{kg}$ was stored at $60^{\circ}$ and $70^{\circ}$ and sampled at weekly intervals to 9 weeks, as described in an earlier paper in this series (Hurrell et al. 1983).

A sample was obtained of freshly-manufactured spray-dried whole-milk powder containing $40 \mathrm{~g}$ water $/ \mathrm{kg}$. A portion ( $50 \mathrm{~g}$ ) was put into store at $-30^{\circ}$ in a hermetic container. A further $400 \mathrm{~g}$ was distributed in layers approximately $18 \mathrm{~mm}$ deep in $100-\mathrm{mm}$ Petri dishes, which were then covered with lids and stacked in two anaerobic jars. The jars were evacuated and filled, one with $\mathrm{O}_{2}$ and the other with $\mathrm{O}_{2}$-free $\mathrm{N}_{2}$. This procedure was repeated to effect a more complete displacement of air and the jars, containing $\mathrm{O}_{2}$ or $\mathrm{N}_{2}$ at atmospheric pressure, were incubated at $37^{\circ}$. Petri dishes were removed at intervals, one from each jar, and their contents transferred to screw-stoppered bottles and deep-frozen. On each such occasion the jars were refilled with $\mathrm{O}_{2}$ or $\mathrm{N}_{2}$ as described above.

To $500 \mathrm{~g}$ of this milk powder was added enough distilled water to increase the moisture content to approximately $100 \mathrm{~g} / \mathrm{kg}$. The wetted powder was mixed in a blender jar and rubbed through a 60 mesh stainless-steel wire sieve. A portion $(50 \mathrm{~g})$ was bottled and frozen, and the remainder stored at $37^{\circ}$ in $\mathrm{O}_{2}$ or $\mathrm{N}_{2}$ and sampled at intervals, as described above.

Spray-dried skimmed-milk powder $(500 \mathrm{~g})$ was similarly adjusted to approximately $100 \mathrm{~g} / \mathrm{kg}$ moisture content, stored at $37^{\circ}$ in $\mathrm{O}_{2}$ or $\mathrm{N}_{2}$, and sampled at intervals to $105 \mathrm{~d}$.

\section{Analytical methods}

Lysine. Total lysine, reactive lysine and lactulosyl-lysine from furosine were defined and measured as described by Hurrell et al. (1983).

Water-soluble vitamins. Samples of the dried-milk preparations were reconstituted in boiled distilled water by gently mixing in a Potter-Elvehjem type homogenizer (for details, see Ford, 1964).

Total ascorbic acid was measured by the microfluorimetric method of Deutsch \& Weeks (1968) adapted to suit the concentrations present in cows' milk.

Riboflavin, nicotinic acid, pantothenic acid and biotin were assayed by standard microbiological procedures (Ford et al. 1953; Chapman et al. 1957). Folate activity was assayed with Lactobacillus casei by an adaptation of the procedure recommended by Herbert (1961) for the assay of folate in blood serum (Ford, 1967). Vitamin B $_{12}$ was assayed with Lactobacillus leichmannii as described by Gregory (1954), and thiamin with Lactobacillus fermenti; the test medium was that of Banhidi (1958) and the milk samples ( $1 \mathrm{ml}$ reconstituted milk) were extracted by heating for $30 \mathrm{~min}$ at $100^{\circ}$ with $20 \mathrm{ml} 0.033 \mathrm{M}$-sulphuric acid. Vitamin $\mathrm{B}_{6}$ was assayed with Kloeckera brevis as described by Barton-Wright (1963), except that the test samples were extracted with $0.055 \mathrm{M}$-hydrochloric acid as recommended by Gregory (1959).

The B-vitamin assays were done once only. They were interpolated in a larger series of assays on milk, in which reference milk samples were included and assayed repeatedly as a check on 'within assay' and 'between assay' variability. The standard errors given with Tables 1-3 pertain to this wider survey, but are quoted here as being representative. 

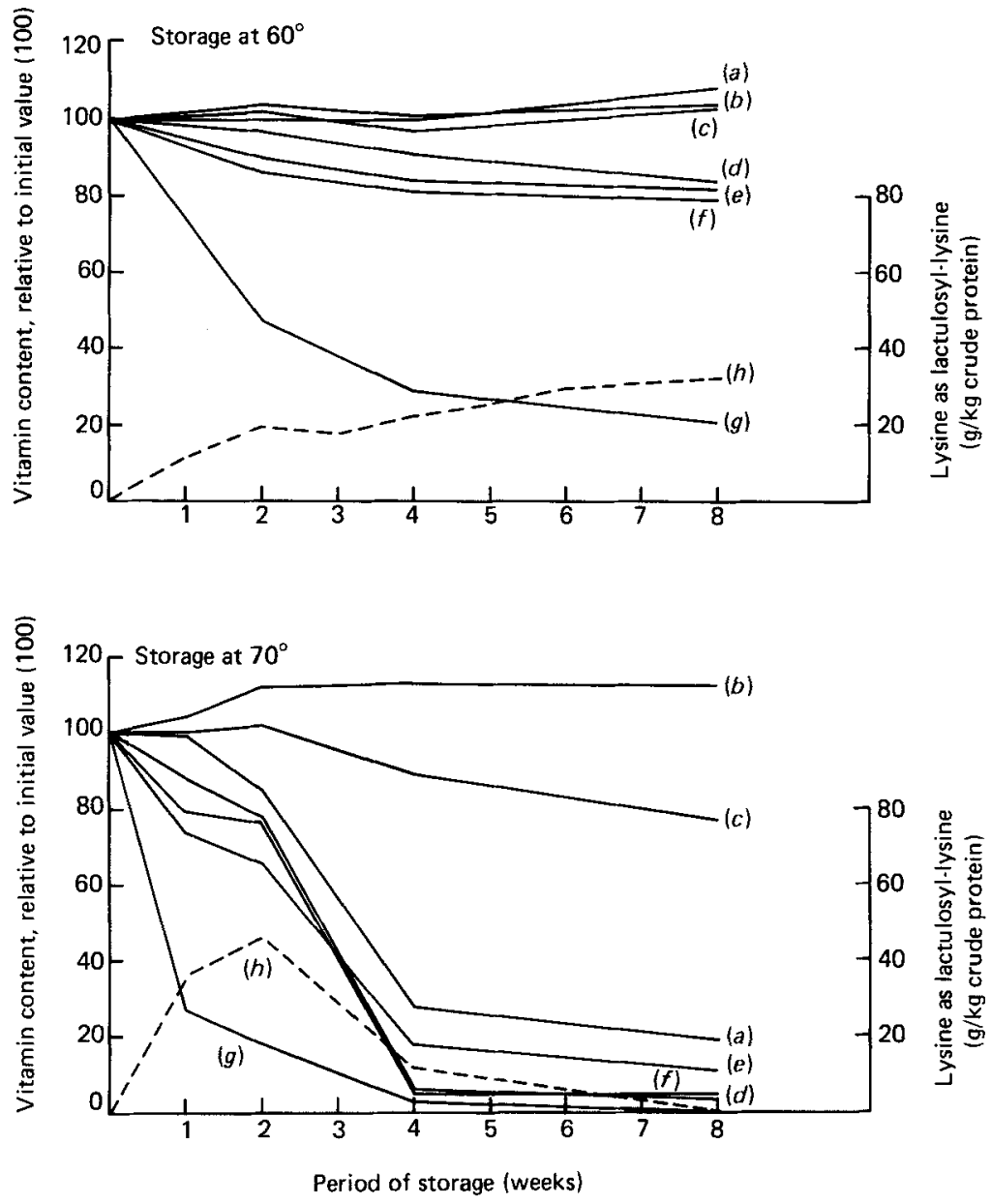

Fig. 1. Content of B-complex vitamins and lactulosyl-lysine in whole-milk powder containing $25 \mathrm{~g}$ moisture $/ \mathrm{kg}$, as measured at intervals during storage at $60^{\circ}$ and $70^{\circ}$. (a) Vitamin $\mathrm{B}_{12},(b)$ nicotinic acid, $(c)$ biotin, $(d)$ pantothenic acid, $(e)$ vitamin $\mathrm{B}_{6},(f)$ thiamin, $(g)$ folate, $(h)$ lysine as lactulosyl-lysine.

\section{RESULTS}

\section{Storage of whole-milk powder at $60^{\circ}$ and $70^{\circ}$}

Table 1 and Fig. 1 show the effect of storage of spray-dried whole-milk at $60^{\circ}$ and $70^{\circ}$ on the content of total and reactive lysine and seven vitamins of the B-complex. During storage for 8 weeks at $60^{\circ}$ there was no change in the content of nicotinic acid, biotin and vitamin $B_{12}$. The same was probably true also for riboflavin, but the results were unaccountably variable and so are held back. The content of thiamin, pantothenic acid and vitamin $\mathrm{B}_{6}$ declined progressively, by approximately $18 \%$ at 8 weeks. Folate was exceptionally labile; more than $50 \%$ was lost by 2 weeks, and $80 \%$ by 8 weeks.

At $70^{\circ}$, as at $60^{\circ}$, nicotinic acid proved entirely stable. The level of biotin remained constant for the first 2 weeks of storage and thereafter declined, by $25 \%$ at 8 weeks. The content of vitamin $B_{12}$, vitamin $B_{6}$, thiamin and pantothenic acid fell sharply after 2 weeks storage, and the rate of loss appeared to accelerate in parallel with the destruction of the 
Table 2. Content of total and available lysine $(\mathrm{mg} / \mathrm{g}$ crude protein (nitrogen $\times 6 \cdot 25)$ ) and of selected water-soluble vitamins in whole-milk powder containing 40 and $100 \mathrm{~g}$ moisture $/ \mathrm{kg}$ and stored at $37^{\circ}$ in oxygen and in $N_{2}$

\begin{tabular}{|c|c|c|c|c|c|c|c|}
\hline $\begin{array}{l}\text { Storage } \\
\text { time (d) }\end{array}$ & $\begin{array}{l}\text { Total } \\
\text { lysine }\end{array}$ & $\begin{array}{c}\text { Reactive } \\
\text { lysine }\end{array}$ & $\begin{array}{c}\text { Lysine as } \\
\text { lactulosyl-lysine } \\
\text { (mg/g crude protein) }\end{array}$ & $\begin{array}{c}\text { Thiamin } \\
(\mu \mathrm{g} / \mathrm{g})\end{array}$ & $\begin{array}{c}\text { Vitamin } B_{6} \\
(\mu \mathrm{g} / \mathrm{g})\end{array}$ & $\begin{array}{l}\text { Folate } \\
\text { (ng/g) }\end{array}$ & $\begin{array}{c}\text { Ascorbic } \\
\text { acid } \\
(\mu \mathrm{g} / \mathrm{g})\end{array}$ \\
\hline & & & $40 \mathrm{~g}$ moisture $/ \mathrm{kg}$ & & & & \\
\hline $\begin{array}{l}\text { Control* } \\
30\end{array}$ & $85 \cdot 8$ & $85 \cdot 8$ & 0 & $4 \cdot 1$ & $4 \cdot 0$ & 300 & 86 \\
\hline $\mathrm{N}_{2}$ & 81.7 & $80 \cdot 1$ & $4 \cdot 2$ & $4 \cdot 0$ & $4 \cdot 1$ & 316 & 78 \\
\hline${ }_{57} \mathrm{O}_{2}$ & $74 \cdot 2$ & 82.5 & $4 \cdot 3$ & 3.8 & $3 \cdot 7$ & 83 & 8 \\
\hline $\mathrm{N}_{2}$ & $75 \cdot 7$ & $74 \cdot 6$ & $5 \cdot 3$ & 3.6 & 3.7 & 303 & nd \\
\hline $\mathrm{O}_{2}$ & $79 \cdot 2$ & $76 \cdot 7$ & $5 \cdot 8$ & $3 \cdot 6$ & $4 \cdot 0$ & 57 & nd \\
\hline $\begin{array}{l}\text { Control* } \\
16\end{array}$ & $86 \cdot 4$ & $86 \cdot 4$ & $\underset{0}{100 \mathrm{~g} \text { moisture } / \mathrm{kg}}$ & $3 \cdot 1$ & $4 \cdot 3$ & 308 & 79 \\
\hline $\mathrm{N}_{2}$ & nd & nd & nd & $2 \cdot 3$ & $1 \cdot 2$ & 308 & nd \\
\hline${ }_{27} \mathrm{O}_{2}$ & nd & nd & nd & $2 \cdot 1$ & 1.9 & 19 & nd \\
\hline $\mathrm{N}_{2}$ & $66 \cdot 8$ & $61 \cdot 7$ & 12.9 & 1.8 & 0.8 & 250 & 0 \\
\hline $\mathrm{O}_{2}^{2}$ & $70 \cdot 3$ & $64 \cdot 2$ & 14.9 & 1.8 & 0.9 & 19 & 0 \\
\hline $\begin{array}{l}\text { SE of analytical } \\
\text { value }\end{array}$ & $\dagger$ & $\dagger$ & $\dagger$ & 0.08 & $0 \cdot 17$ & $9 \cdot 3$ & $\dagger$ \\
\hline
\end{tabular}

nd, not determined. ${ }^{*}$ Stored at $-30^{\circ}$. † Single values.

previously formed lactulosyl-lysine and the onset of advanced Maillard browning. By 4 weeks there remained approximately $6 \%$ of the thiamin and pantothenic acid, $18 \%$ of the vitamin $B_{6}$ and $28 \%$ of the vitamin $B_{12}$. As at $60^{\circ}$, folate was the most labile; $73 \%$ was lost at 1 week, and $97 \%$ at 4 weeks.

Storage of whole-milk powder at $37^{\circ}$

Spray-dried whole-milk powders containing 40 and $100 \mathrm{~g}$ moisture $/ \mathrm{kg}$ were stored at $37^{\circ}$, in $\mathrm{O}_{2}$ and in $\mathrm{N}_{2}$. At $40 \mathrm{~g} / \mathrm{kg}$ moisture content the milk powder did not change in colour during $57 \mathrm{~d}$ of storage. At $100 \mathrm{~g} / \mathrm{kg}$ there was a distinct colour change during storage in $\mathrm{N}_{2}$ for $27 \mathrm{~d}$, from creamy-yellow to pale brown. In $\mathrm{O}_{2}$, however, there was no perceptible colour change.

Table 2 shows the effects on the content of total and available lysine, ascorbic acid, thiamin, folate and vitamin $B_{6}$.

At $40 \mathrm{~g} / \mathrm{kg}$ moisture content there was only a small fall in total lysine and reactive lysine during storage for $57 \mathrm{~d}$. Lactulosyl-lysine was demonstrably 'present' after storage but at low concentration.

The content of ascorbic acid fell only marginally during $30 \mathrm{~d}$ storage in $\mathrm{N}_{2}$, but in $\mathrm{O}_{2}$ the vitamin was largely destroyed. Similarly with folate, there was considerable loss during storage in $\mathrm{O}_{2}$ but no loss in $\mathrm{N}_{2}$. With thiamin there was an apparent loss of approximately $12 \%$ at $57 \mathrm{~d}$, equally in $\mathrm{O}_{2}$ - and $\mathrm{N}_{2}$-stored milk. The content of the remaining B-complex vitamins, nicotinic acid, pantothenic acid, vitamin $B_{6}$, riboflavin, biotin and vitamin $B_{12}$, was unchanged after storage.

At $100 \mathrm{~g} / \mathrm{kg}$ moisture content there was evidence of deterioration in protein nutritional quality after $27 \mathrm{~d}$. Total lysine had fallen by approximately $20 \%$, reactive lysine by almost 


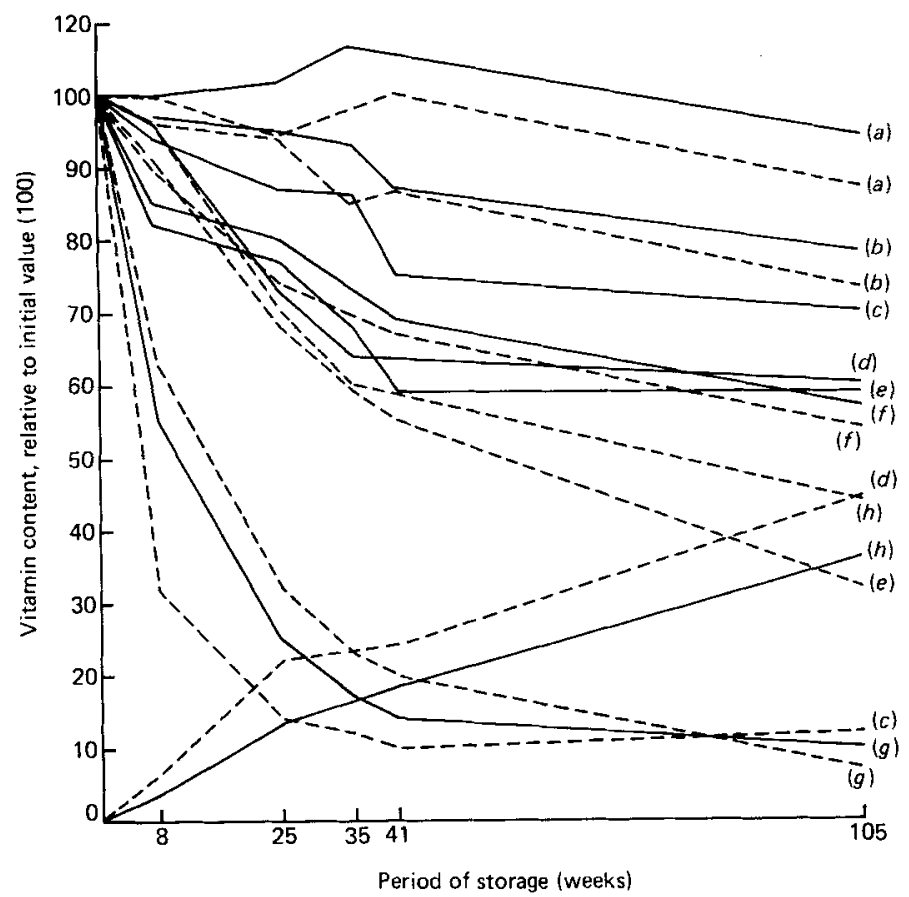

Fig. 2. Content of B-complex vitamins and lactulosyl-lysine in skimmed-milk powder containing $100 \mathrm{~g}$ moisture $/ \mathrm{kg}$, as measured at intervals during storage at $37^{\circ}$ in oxygen (--) or nitrogen (Riboflavin, $(b)$ pantothenic acid, $(c)$ folate, $(d)$ thiamin, $(e)$ vitamin $\mathrm{B}_{12},(f)$ reactive lysine, $(g)$ vitamin $\mathrm{B}_{6},(h)$ lysine as lactulosyl-lysine.

$30 \%$ and approximately $14 \mathrm{mg}$ lysine/g crude protein was estimated to be present as lactulosyl-lysine.

Thiamin content fell progressively, by $41 \%$ in $27 \mathrm{~d}$ storage, and equally with $\mathrm{O}_{2}$ and $\mathrm{N}_{2}$. Vitamin $B_{6}$ proved even more labile, especially on storage in $N_{2}$ which resulted in $71 \%$ loss by $16 \mathrm{~d}$. The pantothenic acid content did not fall significantly. Folate showed no change during $16 \mathrm{~d}$ storage in $\mathrm{N}_{2}$ and only $19 \%$ loss after $27 \mathrm{~d}$. However in $\mathrm{O}_{2}$ the rate of destruction was much faster; $94 \%$ was lost by $16 \mathrm{~d}$. Ascorbic acid was completely destroyed after $27 \mathrm{~d}$, even with $\mathrm{N}_{2}$ storage.

\section{Storage of skimmed-milk powder at $37^{\circ}$}

Spray-dried skimmed-milk containing $100 \mathrm{~g}$ moisture $/ \mathrm{kg}$ was stored at $37^{\circ}$, in $\mathrm{O}_{2}$ and in $\mathrm{N}_{2}$. As with the corresponding whole-milk powder (see p. 359), browning during storage was more advanced in the $\mathrm{N}_{2}$-stored samples. After $105 \mathrm{~d}$ in $\mathrm{N}_{2}$ the product was deep orange-brown in colour, whereas the $\mathrm{O}_{2}$-stored milk was yellow-brown.

Table 3 and Fig. 2 show the effects on the contents of total and available lysine, ascorbic acid, and B-complex vitamins.

Total lysine declined progressively, by $31 \%$ at $105 \mathrm{~d}$. There was a corresponding and somewhat steeper fall in reactive lysine, and a complementary increase in lactulosyl lysine, which was greater in the $\mathrm{O}_{2}$-stored milk.

The content of thiamin and vitamin $B_{12}$ declined during storage at approximately the same rate, and marginally faster in $\mathrm{O}_{2}$. After $105 \mathrm{~d}$ the loss with $\mathrm{N}_{2}$ was approximately $40 \%$ and with $\mathrm{O}_{2}$ approximately $62 \%$. Folate also declined, comparatively slowly in $\mathrm{N}_{2}(30 \%$ loss 
Storage of milk powders

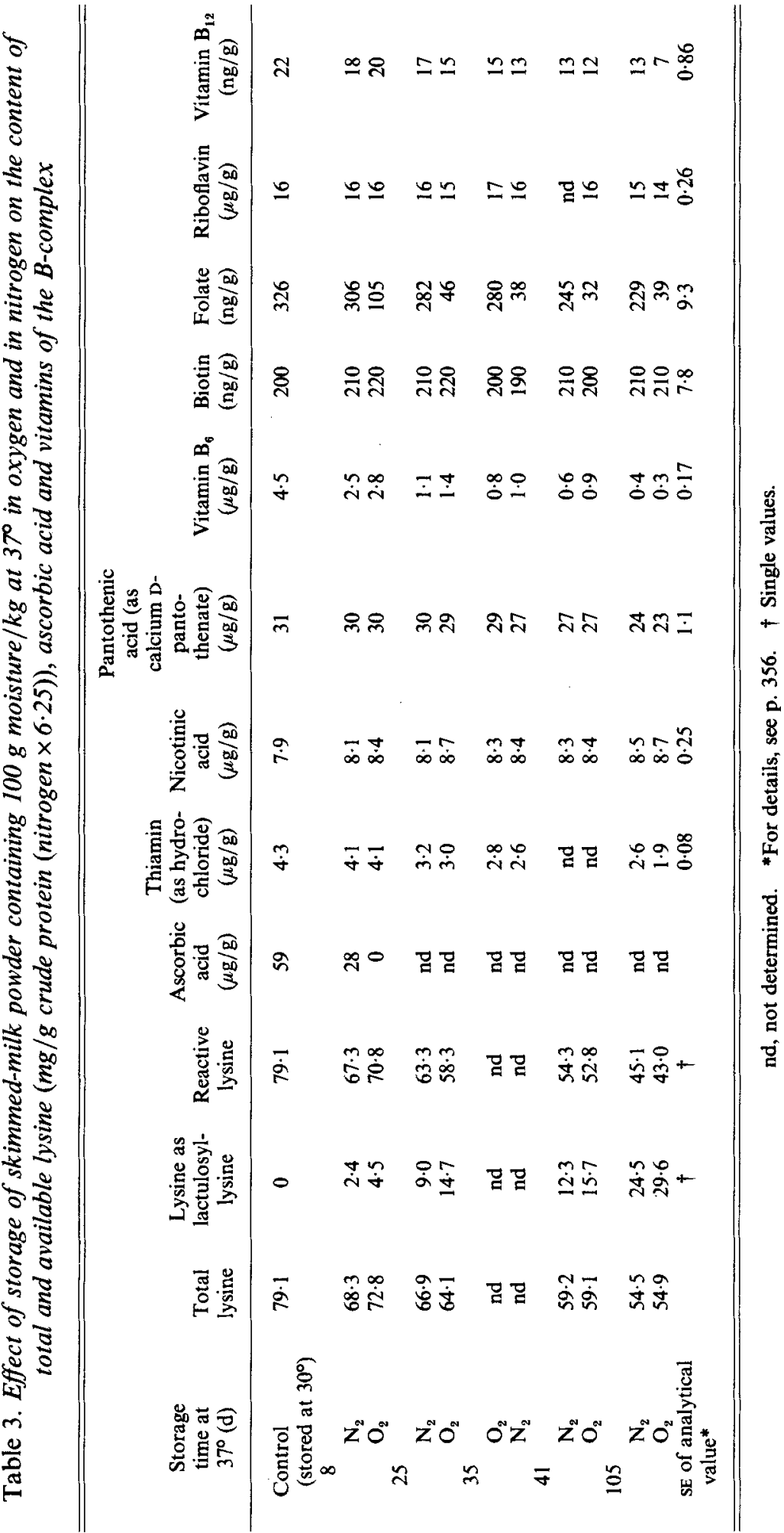


by $105 \mathrm{~d})$ and rapidly in $\mathrm{O}_{2}(86 \%$ loss by $25 \mathrm{~d})$. After the rapid initial loss the folate activity in the $\mathrm{O}_{2}$-stored milk stabilized at approximately $12 \%$ of the level in the control. There was no loss of nicotinic acid or biotin, and an apparent small loss of riboflavin after prolonged storage in $\mathrm{O}_{2}$ was of border-line significance. Pantothenic acid was somewhat less stable and fell by approximately $25 \%$ after $105 \mathrm{~d}$. Vitamin $B_{6}$ was highly labile, again apparently more so in $\mathrm{N}_{2}$ than in $\mathrm{O}_{2}$ (see Table 2), and after $35 \mathrm{~d}$ the loss was approximately $80 \%$.

\section{DISCUSSION}

It is evident from these results that several water-soluble vitamins may be destroyed during the storage of dried-milk powder under unfavourable conditions. Vitamin $B_{6}$, thiamin, folate, vitamin $\mathbf{B}_{12}$, pantothenic acid and ascorbic acid were all labile to different extents. In contrast, nicotinic acid, biotin and riboflavin were comparatively stable.

The destruction of these vitamins appeared to be linked to the progress of Maillard-type reactions, and was strongly influenced by the time and temperature of storage, moisture content and, in some instances, by the presence of $\mathrm{O}_{2}$. In the preceding paper (Hurrell et $a l .1983$ ) we reported that on storage of whole-milk powders at $60^{\circ}$ there was a progressive increase in lactulosyl-lysine. At $70^{\circ}$, lactulosyl-lysine was formed more rapidly and then degraded. We now find that the destruction of vitamins in these powders coincided with the formation of advanced Maillard reaction products from lactulosyl-lysine degradation (Table 1). It would appear, therefore, that vitamin $B_{6}$, thiamin, pantothenic acid and vitamin $B_{12}$ were destroyed by reaction with the advanced Maillard reaction products. However, there were some smaller losses of thiamin, vitamin $B_{6}$ and pantothenic acid during storage at $60^{\circ}$, at which temperature the advanced Maillard reactions had not taken place. Pryidoxamine and thiamin both have free amino groups and might have reacted with lactose directly, forming biologically-inactive products. But the loss of pantothenic acid cannot be accounted for in this way and it may have resulted from the influence of heat alone.

Several workers have reported the instability of vitamin $B_{6}$ in a variety of foodstuffs. Gregory \& Kirk (1978) investigated the stability of $B_{6}$ vitamins in model food-systems stored at $37^{\circ}$ and 0.6 water activity and identified the binding of pyridoxal to protein, forming $\epsilon$-pyridoxyl lysine, as the prime mechanism of degradation. In the model food-systems studied by Gregory \& Kirk (1978), pyridoxamine was rapidly converted to pyridoxal during storage. In milk powder, with its high content of lactose, interaction of pyridoxamine with lactose or advanced Maillard products might be a significant alternative pathway to destruction.

There was no loss of vitamin $B_{6}$ from milk powder containing $40 \mathrm{~g}$ moisture $/ \mathrm{kg}$, during storage at $37^{\circ}$ for $57 \mathrm{~d}$ (Table 2). Mercurio \& Tadjalli (1979) examined tinned milk powder that had been stored for 20 years at room temperature, and found that the vitamin $B_{6}$ content was much the same as that in the freshly-canned product from the same manufacturer, although available lysine, riboflavin and thiamine were lower by 30,50 and $61 \%$ respectively. It seems, therefore, that loss of vitamin $B_{6}$ during storage of dried milk of low moisture content at normal temperatures is a negligible problem.

The presence of $\mathrm{O}_{2}$ was the predominant factor in the destruction of vitamin $\mathrm{C}$ and folate. $\mathrm{O}_{2}$ also had some smaller influence on the loss of vitamin $B_{12}$, vitamin $B_{6}$ and thiamin and on the development of browning. Vitamin $\mathrm{C}$ was the most sensitive of the vitamins to destruction in the presence of $\mathrm{O}_{2}$ and, although its mechanism of degradation in foods depends on many factors (Bauernfeind \& Pinkert, 1971), it is possible that in these milk powders it was due to oxidation followed by a Maillard-type reaction. Ascorbic acid is an enediol and is readily oxidized to dehydroascorbic acid, the diketo form, which reacts readily with free amino groups (Hodge, 1953). However, at $100 \mathrm{~g} / \mathrm{kg}$ moisture content, the ascorbate was completely destroyed after storage under $\mathrm{N}_{2}$ for $27 \mathrm{~d}$ at $37^{\circ}$, whereas at $40 \mathrm{~g}$ 
moisture $/ \mathrm{kg}$ there was comparatively little loss (Table 2). This suggests that ascorbic acid, like thiamin, vitamin $B_{6}$, pantothenic acid and vitamin $B_{12}$ may be destroyed by advanced Maillard-reaction products.

Like thiamin and pyridoxamine, the $\mathrm{N}$-methyl tetrahydrofolate present in milk has a free amino group in the molecule, and destruction of the vitamin in the absence of $\mathrm{O}_{2}$ might similarly be caused by its interaction with lactose or with advanced Maillard reaction products. However, the milk folate is far more sensitive to destruction in the presence of $\mathrm{O}_{2}$. Thus, with milk powder containing $40 \mathrm{~g} / \mathrm{kg}$ moisture there was no loss of folate during storage in $\mathrm{N}_{2}$ for $57 \mathrm{~d}$ at $37^{\circ}$, whereas in $\mathrm{O}_{2}$ there was a $70 \%$ loss after only $30 \mathrm{~d}$. The general picture resembles that reported for liquid milk sterilized by the ultra-high temperature process and aseptically filled into foil-lined cartons. The stability of folate to processing and during subsequent storage was closely associated with the presence of ascorbic acid, and loss of ascorbic acid was determined mainly by the residual concentration of $\mathrm{O}_{2}$ in the milk after processing (Ford, 1967). Supplementation of the milk with ascorbic acid (Ford et al. 1974) or flushing the milk with $\mathrm{O}_{2}$-free $\mathrm{N}_{2}$ (Ford, 1967) effectively removed the residual $\mathrm{O}_{2}$ and stabilized the milk folate.

Our finding that milk powders brown more rapidly during storage under $\mathrm{N}_{2}$ than under $\mathrm{O}_{2}$ was unexpected. There are several reports in the literature that aqueous Maillard systems brown more rapidly in $\mathrm{O}_{2}$ than in $\mathrm{N}_{2}$ (Lewis et al. 1949; Hashiba, 1975, 1976). However, there are also reports to the contrary. Thus, Bohart \& Carson (1955) found that solutions containing glucose and glycine $(0.45 \mathrm{M} ; \mathrm{pH} 6.8$ in phosphate buffer) gave two to three times more colour when heated at $50^{\circ}$ under $\mathrm{N}_{2}$ than under $\mathrm{O}_{2}$. And Gregory \& Kirk (1978) noted that the rate of browning and loss of vitamin $B_{6}$ in model food-systems was lower when they used storage cans with a large head-space volume. They attributed this effect to the larger supply of gaseous $\mathrm{O}_{2}$. A possible explanation is that $\mathrm{O}_{2}$ transforms the intermediate compounds formed on the degradation of the Amadori compound into less reactive substances that do not polymerize to brown pigments. Thus, if under our 'dry' conditions the main pathway for Amadori product degradation was fragmentation of the sugar moiety to give $\alpha$-keto aldehydes or $\alpha$-hydroxyaldehydes such as deoxyglucosone, pyruvaldehyde, glyceraldehyde and glycolaldehyde, then in $\mathrm{O}_{2}$ they might be converted to the corresponding acids, which are less reactive. In $\mathrm{N}_{2}$, the $\alpha$-keto- and $\alpha$-hydroxyaldehydes could react with free amino groups to give brown products. Another explanation might be that browning is a free-radical reaction (Namiki \& Hayashi, 1981) which would be inhibited by $\mathrm{O}_{2}$.

The moisture content of the milk powders had a marked influence on the stability of several of the water-soluble vitamins during storage. From Table 2 it is evident that losses of vitamin $B_{6}$ and thiamin were much greater at $100 \mathrm{~g} / \mathrm{kg}$ than at $40 \mathrm{~g} / \mathrm{kg}$ moisture content; and if we compare values for the $\mathrm{N}_{2}$-stored milk powders the same is true for ascorbate. If these vitamins are assumed to take part in Maillard-type reactions, then such an effect of water content would be expected. It is notable that the vitamins were much more sensitive than lysine to destruction at the higher moisture level.

The moisture content of the milk had no influence on the stability of pantothenic acid. On prolonged storage $\left(105 \mathrm{~d}\right.$ at $\left.37^{\circ}\right)$ of skimmed-milk powder containing $100 \mathrm{~g}$ moisture $/ \mathrm{kg}$ there was a progressive slow loss of pantothenic acid, amounting to approximately $25 \%$ at $105 \mathrm{~d}$ (Table 3), and there was some indication that the rate of loss was greater with $\mathrm{N}_{2}$ storage. Nicotinic acid and biotin were entirely stable under these storage conditions, and the small decline in riboflavin content was of border-line significance. The presence of milk fat had no marked effect on the stability of the water-soluble vitamins, as may be seen by comparing values for whole-milk powder $(100 \mathrm{~g}$ moisture $/ \mathrm{kg}$; Table 2$)$ stored $27 \mathrm{~d}$ at $37^{\circ}$, with those for skimmed-milk powder stored $25 \mathrm{~d}$ under the same conditions (Table 3 ). There was perhaps a slightly greater loss of thiamin and vitamin $\mathbf{B}_{6}$ from the whole-milk powder. 
Our present findings confirm and extend earlier reports (for a review, see Hartman \& Dryden, 1974) that several of the B-complex vitamins in low-moisture milk powders are stable over long periods of storage at temperatures up to approximately $40^{\circ}$, so long as access of light and moisture is prevented. In practice moisture is not a serious problem: most powders contain $20-40 \mathrm{~g}$ moisture $/ \mathrm{kg}$ and are hermetically packed, and would be expected to reach the consumer in temperate countries with no significant loss of product quality or nutritional value. In some of the developing countries, however, a combination of higher temperatures and inadequate storage and transport systems might result in the products being subjected to temperatures in excess of $40^{\circ}$ (cf. Hurrell et al. 1983). Our results indicate that, provided the product retains its natural colour, there should be only small losses of water-soluble vitamins excepting folate and ascorbate, even after storage for several weeks at temperatures up to $60^{\circ}$. In infant formulas the losses would normally be offset by addition of vitamin supplements by the manufacturer. We know of no published information on the fate of folic acid in low-moisture powders stored under $\mathrm{N}_{2}$, but it is clear that large losses of folate and ascorbate may occur even at normal temperatures if $\mathrm{O}_{2}$ is not excluded from the package. In view of the doubts expressed by Barford \& Pheasant (1981) concerning the general assumption that added folic acid is an adequate substitute for the naturally-occurring derivatives of tetrahydrofolic acid, it would seem wise to ensure that as much as possible of the natural vitamin is retained during processing and storage.

The authors are grateful to Dinah R. Bishop, Dorothy J. Knight, J. D. Edwards-Webb and $\mathrm{J}$. Vuichoud for help with the analytical work.

\section{REFERENCES}

Banhidi, Z. (1958). Acta chem. scand. 12, 517.

Barford, P. A. \& Pheasant, A. E. (1981). Br. med. J. 282, 1793.

Barton-Wright, E. C. (1963). Practical Methods for the Microbiological Assay of the Vitamin B Complex and Amino Acids. London: United Trade Press Ltd.

Bauernfeind, J. C. \& Pinkert, D. M. (1971). Adv. Fd Res. 18, 219.

Bohart, G. S. \& Carson, J. F. (1955). Nature, Lond. 175, 470.

Chapman, H. R., Ford, J. E., Kon, S. K., Thomson, S. Y., Rowland, S. J., Crossley, E. L. \& Rothwell, J. (1957). J. Dairy Res. 24, 191.

Deutsch, M. J. \& Weeks, C. E. (1968). J. Ass. Off. Anal. Chem. 48, 1248.

Finot, P. A., Deutsch, R. \& Bujard, E. (1981). In Progress in Food and Nutrition Science, vol. 5 Maillard Reaction in Foods, p. 345 [C. Eriksson, editor]. Oxford: Pergamon Press.

Ford, J. E. (1964). Br. J. Nutr. 18, 449.

Ford, J. E. (1967). J. Dairy Res. 34, 239.

Ford, J. E., Gregory, M. E., Porter, J. W. G. \& Thompson, S. Y. (1953). Proc. XIIth int. Dairy Congr. 3, 1282.

Ford, J. E., Porter, J. W. G. \& Thompson, S. Y. (1974). Proc. XIXth int. Dairy Congr. 1E, 567.

Gregory, M. E. (1954). Br. J. Nutr. 8, 340.

Gregory, M. E. (1959). J. Dairy Res. 26, 203.

Gregory, J. F. \& Kirk, J. R. (1978). J. Fd Sci. 43, 1801.

Hartman, A. M. \& Dryden, L. P. (1974). In Fundamentals of Dairy Chemistry, 2nd ed, Chpt. 7 [B. H. Webb, A. H. Johnson and J. A. Alford, editors]. Westport, Connecticut: Avi Publishing Company, Inc.

Hashiba, H. (1975). J. agric. Fd Chem. 23, 539.

Hashiba, H. (1976). J. agric. Fd Chem. 24, 70.

Herbert, V. (1961). J. clin. Invest. 40, 81.

Hodge, J. E. (1953). J. agric. Fd Chem. 1, 928.

Hurrell, R. F., Finot, P. A. \& Ford, J. E. (1983). Br. J. Nutr. 49, 343.

Lewis, W. M., Esselen, W. B. \& Fellers, C. R. (1949). Ind. Eng. Chem. 41, 2591.

Mattick, A. T. R., Hiscox, E. R., Crossley, E. L., Lea, C. H., Findlay, J. D., Smith, J. A. B., Thompson, S. Y. \& Kon, S. K. (1945-6). J. Dairy Res. 14, 116.

Mercurio, K. C. \& Tadjalli, V. A. (1979). J. Dairy Sci. $62,633$.

Namiki, M. \& Hayashi, T. (1981). In Progress in Food and Nutrition Science, vol. 5 Maillard Reaction in Foods, p. 81 [C. Eriksson, editor]. Oxford: Pergamon Press.

Sharp, P. F., Shields, J. B. \& Stewart, A. P. (1945). Proc. Inst. Fd Tech. 6, 54. 